\title{
New way of investigating ICT-enhanced teaching in TAFE Australia: Disciplinary focused
}

\author{
Md Shahadat Hossain Khan and Sue Gregory
}

Islamic University of Technology and University of New England

\begin{abstract}
Teachers' ways of using ICT (Information and Communication Technology) in various disciplines is a recent issue in the higher educational research paradigm. In order to extend previous findings in relation to this issue, this research proposes an in-depth investigation focusing on vocational teachers' qualitatively diverse ways of using ICT in different disciplines. A cohort of 11 teachers from three TAFE (Technical and Further Education) institutions of NSW, Australia, were purposively chosen aiming to ensure adequate variations in disciplines, gender, and experience of using ICT. The phenomenographic research approach was considered as the theoretical and methodological underpinning which guided the participant selection, data collection and data analysis. The findings revealed that disciplines have very limited influence on using ICT in TAFE teaching. It further discerned four categories of description: tool, content, subject, and student focused. The findings provide useful information towards improving vocational teaching practices in different disciplines and working as an input for improving teacher professional development program (TPD). In order to generalise these findings, an extended research with a wider sample is recommended.
\end{abstract}

Keywords: Conceptions, ICT use, vocational education, phenomenography, TAFE

\section{Introduction}

A significant amount of research has been carried out focusing on identifying the benefits of using Information and Communication Technology (ICT) in education (Jamieson-Proctor, et, al., 2006; Ali, 2020). Few of them were investigated on the conceptions of ICT in teaching higher education and provided useful knowledge (González, 2009; González, 2010; Khan \& Markauskaite, 2018). In the last decade, researchers were investigating how teachers are using ICT in different disciplines (Hammond, \& Bennett, 2002; Mercader \& Gairín, 2020). Neumann (2001) identified four broad categories of disciplines, such as hard pure (science), hard applied (technologies), soft pure (humanities and social sciences) and soft applied (professions from social science). For example, Mercader and Gairín (2020) found that teachers from arts and humanities disciplines provide unenthusiastic perceptions compared to science and technology teachers. In contrast, Czerniewicz and Brown (2007) provide evidence on the lack of disciplinary differences in using ICT among different disciplines. Critical literature review on this area - disciplinary variation on using ICT in higher education - guides us to three important aspects: first, the use of ICT in different disciplines provides commonalities and differences. Second, prior studies have shown less interest in why teachers are using ICT in a common way (commonality) or different way in different disciplines. Third, lack of qualitative research was found to investigate why teachers conceived these experiences while using ICT in various disciplines. In order to respond these three aspects, this research outstretched its focus on investigating TAFE (Technical and Farther Education) teachers' experience on using ICT in different disciplines, particular focus was on two broad disciplines where ICT is widely used, that were hard applied (technologies) and soft applied (professions from social science). It is important to note that, the variation of using ICT in different subjects was not our focus rather how it was approached in the hard applied and soft applied disciplines was the main research purpose. Aligning with this objective, this research chose two research questions (i) 'Does the discipline have influence on using ICT in TAFE teaching?' (ii) 'What are the teachers' conceptions of using ICT in their teaching when they are teaching in diverse subjects of two broad disciplines?'

\section{Methodology}

The theoretical and methodological underpinning of this research is based on phenomenography. It is a qualitative research approach primarily focused on people's experience of a phenomenon which is presented via a qualitative limited numbers of categories (Marton, 1981; 1986). A substantial number of research has been 
carried out focusing on identifying conceptions of a phenomenon in higher education that has benefited from this phenomenography (González, 2009; González, 2010; Khan \& Markauskaite, 2018). Thus, participants selection, data collection, data analysis of this research followed phenomenographic principles.

\section{Participants}

Eleven teachers from three TAFE institutions of NSW, Australia were purposively selected as the sample of this research by following recommendations from Trigwell (2000), who suggested ten to fifteen participants will be required for creating reasonable variation in identifying limited categories, and Åkerlind, (2005) who recommended sample selection should be followed by maintaining variation in experience, that is sought out in terms of disciplines, level of experiences, teaching position, and gender. All the participants had a minimum of one-year experience in using ICT in their teaching. The characteristics of the participants are listed in Table 1.

Table 1. Participant's characteristics

\begin{tabular}{l|c|c|c|c|c|c}
\hline Teacher ID & Gender & Subject & Discipline & $\begin{array}{c}\text { Employment } \\
\text { level }\end{array}$ & $\begin{array}{c}\text { Year of } \\
\text { teaching } \\
\text { experience } \\
\text { with ICT }\end{array}$ & $\begin{array}{c}\text { Variation } \\
\text { of using ICT } \\
\text { in different } \\
\text { disciplines }\end{array}$ \\
\hline DH-NSI-1 & Male & Computer & Hard applied & Full Time & 16 years & yes \\
\hline GR-WSI-2 & Male & Computer & Hard applied & Full Time & 17 years & yes \\
\hline IS-WSI-3 & Female & Computer & Hard applied & Full Time & 10 years & yes \\
\hline JT-WSI-4 & Male & Mechanical & Hard applied & Full Time & 7 years & no \\
\hline LS-WSI-5 & Male & Mechanical & Hard applied & Full Time & 7 years & yes \\
\hline LY-NSI-6 & Male & Computer & Hard applied & Full Time & 13 years & yes \\
\hline PM-WSI-7 & Female & Civil & Hard applied & Part Time & 4 years & yes \\
\hline SR-WSI-8 & Female & Computer & Hard applied & Full Time & 10 years & yes \\
\hline VD-WSI-9 & Male & Accounting & Soft applied & Part Time & 17 years & yes \\
\hline YY-NSI-10 & Female & Computer & Hard applied & Full Time & 4 years & yes \\
\hline MB-WSI-11 & Male & Event & Soft applied & Part Time & 9 years & yes \\
\hline
\end{tabular}

\section{Data Collection}

Interview is the preferred data collection technique in phenomenographic research approach (Akerlind, 2005). A semi-structured interview schedule was constructed to conduct interviews among the selected participants. Interviews were conducted after participant consent letters were signed from the selected teachers. The participants were asked selected questions, for example, 'What is the purpose of using ICT in your teaching?' and 'Do you use ICT in your teaching differently in various subjects?' During the interviews, the researcher allowed participants to express their experiences fully and elaborately. The researcher asked follow-up questions to gain a richer understanding about the topic. For example, 'Could you explain that further?', 'What do you mean by that?' The interviews were recorded, with an average duration of 30-40 minutes.

\section{Data analysis}

At the conclusion of the interviews, recorded data was transcribed. In phenomenography, there is no single technique to analyse data (Marton, 1986). For instance, González (2010) applied five steps, whereas Khan (2015) employed seven steps. In this research, González's (2010) five steps were followed for analysing data: (i) the transcripts were read several times (whole method) with the aim of gaining understanding about the central meaning (conceptions); (ii) more focused reading was imposed with the aim of identifying similarities and dissimilarities among the transcripts with an open mind; (iii) initial categories were identified based on the similarities and dissimilarities; (iv) in order to confirm the initial categories with limited numbers, the transcripts were read again and verified with the citation (transcripts); and (v) the final outcome was decerned by following González's (2010) recommendation: each category having distinct aspects and supported by the transcripts.

\section{Findings}

After the analysis of the interview data, four categories of description were identified as an outcome space. Thus, the purpose of using ICT in their teaching is: 
- Category A: Tool focused

- Category B: Content focused

- Category C: Subject focused

- Category D: Student focused

Each of the category is discussed briefly with the citations from the transcripts.

\section{Category A: Tool focused}

Vocational teachers perceive, in Category A, that ICT is a simple tool that facilitates regular teaching in different subjects. Their perceived views are categorised into three distinct purposes of using ICT in their teaching.

- Firstly, teachers expressed the purpose of using ICT in their teaching was to meet the basic requirement of teaching a subject via ICT.

I mean use of audio-visual, use of net [Internet], getting resources from the net, using video clips, that sort of things. That's the same for all the subjects.

- Secondly, vocational teachers considered using ICT in their teaching was to show students how to gather information from online.

Sometimes I use ICT because I want them [students] to learn how to collect information and research information.

- Thirdly, some teachers expressed their purpose of using ICT was to avail visual facilities from the ICT resources.

Sometimes I use ICT because it has a visual stimulus which I can't convey without some sort of visual medium.

This category demonstrates that vocational teachers use ICT in different subjects for the sake of readily available ICT tools to ease their teaching.

\section{Category B: Content focused}

Category B represents the vocational teachers' views on the purpose of using ICT in teaching different subjects, revealing that teachers usually chose ICT tools based on the nature of content of the subject. Thus, the topic of the subject determines the preference of selecting ICT-enhanced teaching practices.

The way I teach my marketing is different to the way I teach the business docs, mainly because the topic material is different.

For example, teachers needed to visualise models or figures to students and therefore, chose a Smartboard instead of other tools available to them.

I'm teaching business docs without having to use Excel, Microsoft Word, PowerPoint. I'll jump up to the Smartboard, follow my cursor around and do the things. So, the Smartboard is useful in that.

Vocational teachers, in this category, further view that every kind of ICT tool may not be appropriate for teaching particular content. The basic requirement is that the ICT tools need to fit the purose.

So, you know, I wouldn't use flash for project management and similarly, I wouldn't use MS Project for $2 D$ animation. It just doesn't fit. So the tool has to fit the type of contents [that need to deliver] delivery.

Therefore, teacher's preference of choosing ICT tools for their instruction depends mainly on the type of contents (topics) requiring delivery. 


\section{Category C: Subject focused}

Within Category C, teachers view of using ICT in teaching generally depends on the nature of subjects. Teachers select ICT tools based on the types of subjects being taught. In this Category, the subject's nature (difficulties, complexity) determines the types of ICT tools for using in their teaching.

It [way of using ICT) really depends on how much practice is involved in it, and that's why you do it differently. It all depends on the subject. You can't use the same approach to teach for every single subject. It all depends on what you want to get out of it and the nature of the subject.

Some teachers in this category also expressed their purpose of using ICT was to maintain communications among students. For example, few subjects may need collaboration, meeting online, and other types of communication among teachers, students and sometimes employers. In contrast, other subjects may not need these sorts of collaboration.

In project management, you work on projects so we have a simulated environment in a classroom and for that, I might use a forum. But, excuse me, I will also use some obviously additional tools such as project, in order to manage their (I use Microsoft Project) project activities. We also collaborate on forums because in a real environment you have continuous team meetings... They have some access to WebEx so that they can have face to face meeting also with their clients, so they might use those tools.

The purpose of choosing ICT tools, in this category, mainly depends on the subjects' characteristics (context, nature, complexity).

\section{Category D: Student focused}

In this category the focus of choosing ICT tools for teaching is shifted from the subject's nature to the student's nature. Vocational teachers perceived that teachers' decisions of selecting ICT tools for their teaching were influenced by the characteristics of students, such as students' level, background, mode of stream (mainstream or part time), student preference, and the like.

So, it's not up to which subject I'm doing... I will consider who is my audience, where is my student, what is my student's background.

When I was teaching Linux for more advanced students at night, I had students who were doing PhDs, who were doing engineering degrees, coming to that as an extra subject in TAFE and some of those were learning faster than I could teach them... I ran a forum for them to exchange ideas and ask each other which I did not have for industrial networking [subject].

Teachers expressed their views that students' group or mode of delivery may influence the preference of choosing ICT tools in their teaching.

I won't consider it [ICT choice] as a subject, rather which group I have to teach. So, I teach the mainstream students, I teach the evening class and I use ICT in a different way to do my delivery, but it's not up to the subject, but it depends on the audience, student groups.

Therefore, in this category, the purpose of choosing ICT tools is not only limited to subject's complexity but more on a students' background.

\section{Results and Discussion}

This research was conducted to discern TAFE teachers' experience on using ICT in different disciplines. To investigate this objectively, two research questions were identified. The findings of the first research question, 'does the discipline have influence on using ICT in TAFE teaching?' revealed that the discipline has a very minor influence on choosing ICT in teaching. For example, 91\% teachers (10 out 11 teachers) expressed their experience in using ICT in different subjects of their disciplines using almost the same style (see Table 1). This result is in line with the previous studies which likewise provided evidence that the use of ICT in teaching different disciplines is common (see, Czerniewicz \& Brown, 2007). However, the result contradicts large 
numbers of prior studies which revealed that arts and humanities perceived understanding of using ICT is different than science and engineering disciplines (see, Hammond, \& Bennett, 2002; Mercader, \& Gairín, 2020). The reason of identifying this discontinuity might be due to context of this research, which was mainly focused on vocational education in NSW, Australia.

The findings of the second research question, 'what are the teachers' conceptions of using ICT in their teaching when they are teaching in diverse subjects of two broad disciplines?', discerned four categories of description, that is, the purpose of using ICT in their teaching is tool, content, subject, and student focused. It is clear from this phenomenographic research that TAFE teachers use ICT in their teaching for different purposes. Few teachers use ICT for facilitating their teacher focused teaching by considering ICT as simply a teaching tool. Some of them extended their reason of using ICT from tool focused to content focused. This means they considered using ICT depending on the nature of the content. Different contents may require different types of ICT tools in their teaching. A group of teachers viewed that their reason of choosing ICT in their teaching was for engaging students in the subject. This category is higher than previous category (B: content focused) because a teacher's intention to choose as a ICT tool was to encourage students towards practice of the particular subject, whereas the previous category was to focus on a teacher's intention in content delivery (students' engagement was not focused). Another group of teachers perceived that choosing ICT for their teaching was mainly influenced on students' nature. They believed that some ICT may not be appropriate for engaging the entire class. Category D is higher than Category $\mathrm{C}$ because it not only carries aspect of students' engagement from previous Category C, but also presents a reasons of choosing it based on students' backgrounds. Students' engagement and participations in the lower categories (Category A and B) were rarely found rather they emphasised more on content focused teaching approaches. Thus, the category of description maintains a hierarchical relationship.

The findings of this research are consistent with prior phenomenographic research. For example, the four categories could be categorised as teacher-centered (Category A, B) and student-centered (Category C, D) (González, 2009; González, 2010; Khan \& Markauskaite, 2018). However, this research is a new way of investigating the same phenomenon. More specifically, prior research focused on different ways teachers conceived ICT-enhanced teaching in higher education, whereas this research investigated the same phenomenon aiming to find out what are the reasons for using ICT differently in different disciplines.

\section{Implication}

This research provides useful and new knowledge contributing to literature and practices. In relation to practice, vocational teachers will gain useful insight from the identified categories. It will provide them knowledge on ways teachers could choose ICT for their teaching. Course designers will benefit after achieving these four categories to facilitate them designing courses focusing on a myriad of ICT tools. Lastly, teacher professional development programs will benefit by considering how to integrate ICT in teaching and learning.

\section{Limitation}

One of the limitations of this research is its sample size. However, a significant number of phenomenographic studies were found in prior literature that had sample sizes smaller than this research (see González, 2009). This research is context dependent which will not be able to be generalised for wider contexts (countries). It relies on only data collected from interviews. However, most of the prior phenomenographic studies heavily depend on interview data and provide useful knowledge. Only two participants were selected from two subjects of 'soft applied' disciplines whereas nine were from the three subjects of 'hard applied' disciplines. The outcome of this research is from a pilot, which has limited scopes.

\section{Conclusion}

The findings provide four categories of description which are an initial outcome from the preliminary analysis. The relationships among the categories will be identified in the forthcoming article after completing full analysis of the datasets. Moreover, future research may be conducted considering a wider sample size maintaining a balance representation from both disciplines and mixing both interview and observation techniques.

\section{Acknowledgements}

We would like to thank Mr. Benadjih Oiriddine Abdou, Lecturer, Department of Technical and Vocational Education (TVE), Islamic University of Technology (IUT) for his editorial support. 


\section{Reference}

Åkerlind, G. S. (2005). Variation and commonality in phenomenographic research methods. Higher Education Research \& Development, 24(4), 321-334.

Ali, W. (2020). Online and remote learning in higher education institutes: A necessity in light of COVID-19 pandemic. Higher Education Studies, 10(3), 16-25.

Czerniewicz, L., \& Brown, C. (2007). Disciplinary differences in the use of educational technology. In In International Conference of E-Learning.

González, C. (2009). Conceptions of, and approaches to, teaching online: A study of lecturers teaching postgraduate distance courses. Higher Education, 57(3), 299

González, C. (2010). What do university teachers think eLearning is good for in their teaching? Studies in Higher Education, 35(1), 61-78.

Hammond, N., \& Bennett, C. (2002). Discipline differences in role and use of ICT to support group-based learning. Journal of Computer Assisted Learning, 18(1), 55-63.

Jamieson-Proctor, R. M., Burnett, P. C., Finger, G., \& Watson, G. (2006). ICT integration and teachers' confidence in using ICT for teaching and learning in Queensland state schools. Australasian Journal of Educational Technology, 22(4).

Khan, S. H. (2015). Emerging conceptions of ICT-enhanced teaching: Australian TAFE context. Instructional Science, 43(6), 683-708.

Khan, M. S. H., \& Markauskaite, L. (2018). Technical and Vocational Teachers' Conceptions of ICT in the Workplace: bridging the gap between teaching and professional practice. Journal of Educational Computing Research, 56(7), 1099-1128.

Marton, F. (1981). Phenomenography -Describing conceptions of the world around us. Instructional Science, 10(2), 177-200. doi: 10.1007/bf00132516

Marton, F. (1986). Phenomenography: a research approach to investigating different understandings of reality. Journal of Thought, 21(3), 28-49.

Mercader, C., \& Gairín, J. (2020). University teachers' perception of barriers to the use of digital technologies: the importance of the academic discipline. International Journal of Educational Technology in Higher Education, 17(1), 1-14.

Neumann, R. (2001). Disciplinary differences and university teaching. Studies in higher education, 26(2), 135146.

Trigwell, K. (2000). A phenomenographic interview on phenomenography. In J. Bowden \& E. Walsh (Eds.), Phenomenography (pp. 63-82): Melbourne: RMIT University Press.

Khan S., Gregory, S. (2021). 2021). New way of investigating ICT-enhanced teaching in TAFE Australia: Disciplinary focused. In Gregory, S., Warburton, S., \& Schier, M. (Eds.), Back to the Future - ASCILITE ' 21. Proceedings ASCILITE 2021 in Armidale (pp. 213-218). https://doi.org/10.14742/ascilite2021.0132

Note: All published papers are refereed, having undergone a double-blind peer-review process.

The author(s) assign a Creative Commons by attribution licence enabling others to distribute, remix, tweak, and build upon their work, even commercially, as long as credit is given to the author(s) for the original creation.

(C) Khan S., Gregory, S. 2021 